\title{
TOXICITY OF Aaptos suberitoides EXTRACT ON TIGER SHRIMP Penaeous monodon POST LARVAE
}

\section{TOKSISITAS Ekstrak Aaptos suberitoides terhadap Pasca Larva Udang Windu Penaeous monodon}

\author{
Rosmiati $^{1 *}$ and Emma Suryati ${ }^{1}$ \\ ${ }^{1}$ Institute for Coastal Aquaculture (RICA), Jl. Makmur Dg. Sitakka No. 129 Maros, North Sulawesi, Indonesia 90512 \\ *Corresponding Author: emirosmiati@yahoo.com
}

Article history:

Received: 10 April 2014; Revised: 18 Juli 2014; Accepted: 25 Juli 2014

\begin{abstract}
Marine sponges contain bioactive compounds which can be used not only for human diseases treatment but also for animal diseases treatment. Aaptos suberitoides has been reported to have potential as antibacterial against Vibrio harveyi in vitro. This study aims to study the toxicity effect of Aaptos suberitoides extract on tiger shrimp Penaeous monodon post larvae. The toxicity study of this extract was done by using soaking method. This experiment used Completely Randomized Design with 6 treatments of $A$. suberitoides extract namely A). 0 ppm, B). 31.3 ppm, C). 62.5 ppm, D). 125, E). 250 ppm, and F). 500 ppm. Each treatment consisted of 3 replications. Findings showed that $A$.suberitoides butanol extracts at the concentration up to125 ppm were safe for tiger shrimp post larvae. On the other hand, the higher concentration of that gave a toxic effect on the post larvae. The lowest mortality $(20.0 \%)$ was obtained on the post larvae treated with butanol extract at the concentration of $31.3 \mathrm{ppm}$ and the highest was found at the concentration of 500 ppm (97.0\%). Compared to the negative control $(0 \mathrm{ppm})$, there was no any difference exhibited by the post larvae treated with butanol extract at the concentrations of $31.3,62.5$, and $125 \mathrm{ppm}$. Beside that, these concentrations gave a normal growth and no abnormal behavior. The histological observation did not also show damage on post larvae haepatopancreas tissue.
\end{abstract}

Keywords: Sponge, Aaptos suberitoides, Vibrio harveyi, vibriosis, Penaeous monodon

\section{ABSTRAK}

Spons mengandung senyawa bioaktif yang dapat digunakan untuk mengobati penyakit manusia dan hewan. Aaptos suberitoides dilaporkan mempunyai potensi sebagai antibakterial terhadap Vibrio harveyi. Penelitian ini bertujuan untuk mengetahui pengaruh ekstrak $A$. suberitoides terhadap pasca larva udang windu Penaeous monodon. Kajian ketoksikan dari ekstrak ini dilakukan menggunakan metode perendaman. Penelitian menggunakan Rancangan Acak Lengkap dengan 6 perlakuan dan 3 ulangan dengan konsentrasi ekstrak butanol A.suberitoides yang terdiri dari; A). 0 ppm, B). 31,3 ppm, C). 62,5 ppm, D). 125, E). 250 ppm, dan F). 500 ppm. Hasil penelitian menunjukkan bahwa ekstrak butanol A.suberitoides sampai konsentrasi 125 ppm aman atau tidak memberikan efek toksik terhadap pasca larva. Sedangkan, pada konsentrasi yang lebih tinggi adalah toksik pada pasca larva. Kematian pasca larva paling tinggi $(20,0 \%)$ dijumpai pada pasca larva yang diberi perlakuan ekstrak pada konsentrasi 31,3 ppm dan yang terendah diberikan oleh pasca larva yang diberi ekstrak pada konsentrasi 500 ppm $(97,0 \%)$. Pada penelitian ini ditemukan tidak ada perbedaan yang ditunjukkan oleh pasca larva yang diberi perlakuan ekstrak pada konsentrasi 31,3, 62,5, dan 125 ppm dibandingkan dengan kontrol (tanpa ekstrak butanol). Ketiga konsentrasi ekstrak tersebut juga memberikan pertumbuhan dan tingkah laku yang normal. Pengamatan histologikal juga tidak menunjukkan kerusakan pada jaringan haepatopankreas pasca larva.

Kata Kunci: Spons, Aaptos suberitoides, Vibrio harveyi, vibriosis, Penaeous monodon

\section{Introduction}

Vibriosis luminescence is a disease caused by Vibrio species. This disease has been the main causative agent of mass mortality in shrimp culture
(Karunasagar et al., 1994; Lavilla-Pitogo et al., 1996; Chen et al.,2000; Soundarapandian, P. \& Babu, 2010; Traifalgar et al., 2013). Vibriosis luminescence attacks all stages of shrimp reared from seeding in the 
hatchery until growth out in the pond. Mortalities of Penaeous monodon larvae associated with luminescence have been observed in hatcheries in Indonesia (Sunaryanto \& Mariam, 1986; Kadriah et al., 2012), Thailand (Tansutapanit \& Ruangpan, 1987; Robertson et al., 1998; Pasharawipas et al., 2011) \& Philippine (Lavilla-Pitogo et al., 1990; Rattanachuay, 2010; Traifalgar et al., 2013).

The Philippine isolate of Vibrio harveyi was highly pathogenic, which could infect shrimp at various life stages and could cause up to $100 \%$ mortality (LavillaPitogo et al., 1990). The loss in production of shrimp due to vibriosis has been estimated at approximately 30.8 metric tons or US\$264 million per year in Japan (Inouye, 1996). In 1991, most shrimp hatcheries in Java were hit by a disease caused by luminous bacteria and resulted in a decrease of $70 \%$ larval production with shrimp loss estimated at more than US \$ 85 millions (Prayitno \& Latchford, 1995). Before the outbreaks of this bacterial disease, Thailand earns an average of US \$1.8-2.3 billion per year, but in 2005 Thailand suffered an overall loss of US $\$ 1$ billion of shrimp production (Tanticharoen, 2008). Even in the end of 2011, farmers in Pangkep and Pinrang, South Sulawesi, Indonesia obtained luminescent black tiger shrimp grown out in their ponds in the evening and suddenly in the period of three days, the shrimp were found to die up to $90 \%$. Analysis on diseases shrimp was found the presence of the great number of Vibrio harveyi. Pathogenicity test done on this bacterium showed that it was pathogenic at $10^{7} \mathrm{CFUs} / \mathrm{ml}$ to 14 days of tiger shrimp post larvae with the $\mathrm{LC}_{50}$ value of $10^{6} \mathrm{CFU} / \mathrm{mL}$ after 48 hours of immersion (Khodria et al., 2012). Indonesian government through Ministry of Marine Affairs and Fisheries program plans to make Indonesia as the world's biggest aquaculture producer in 2015, well known as "The Blue Revolution Policy" with the increase of production amounting to $353 \%$ of production in 2010 (Usman, 2013). Australian Black Tiger prawn industry also wants to increase production from 5000 ton to 12,500 ton by 2020 (CSIRO scientists and industry partners). This gives an idea of the importance of disease control to the shrimp industry.

Current antibiotics on the market such as chloramphenicol, oxytetracycline and streptomycin have been used for many years to prevent vibriosis. Nevertheless, the use of these commercial drugs is problematic because they have been ineffective and cause several side effects (Baticados et al., 1990; Sengupta et al., 2003; Raffi \& Suresh, 2011). Natural products, particularly those from marine sponges, have been regarded as sources of bioactive metabolites with promising activity against many important diseases (Ninawe, 2007). Several methanol extracts of sponge were described as having potential for vibriosis treatment such as methanol extract of Geodia sp., which was active on Vibrio harveyi (Isnansetyo et al., 2009) and Callyspongia pseudoreticulata and Halichondria cartilogenia, which were active on Vibrio harveyi, Vibrio mimicus, Vibrio alginolyticus, and Vibrio costicola (Suryati et al., 1997; 1998; Rosmiati et al., 2011a). Another example is the methanol extract of Denrilla nigra, which is active against Vibrio harveyi and Vibrio algynoliticus and this extract was proven to be effective in preventing bacterial disease (Selvin and Lipton, 2004; Selvin et al., 2011).

Research on the potential use of bioactive compounds from sponges for disease prevention, particularly vibriosis, has been continued. It was previously reported that Aaptos suberitoides butanol extract showed a strong antibacterial activity against Vibrio harveyii with the inhibition zone of $17.2 \pm 0.1$ $\mathrm{mm}$ (Rosmiati et al., 2014). However, the effect of this extract on tiger shrimp post larvae needs to be determined before being used for controlling Vibrio harveyii in the field. It was done to prevent mortality of post larvae due to toxic effect of Aaptos suberitoides butanol extract. Here, we reported non toxic effect of this extract sponge.

\section{Material and Methods}

\subsection{Sponge Collection and Preparation}

Marine sponge Aaptos suberitoides was collected from Barrang Lompo Islands, South Sulawesi latitude (-5.047 degrees) $5^{\circ} 2^{\prime} 49^{\prime \prime}$ south of the Equator and longitude (119.329 degrees) $119^{\circ} 19^{\prime} 44^{\prime \prime}$ east of the Prime Meridian by SCUBA diving at a depth of 8-12 $\mathrm{m}$ on August 16, 2010.Sponge was kept in a sealed plastic bag, placed in acool box in a fresh condition and brought to RICA, Maros. The fresh sponge was cut into small pieces and dried in an oven at the temperature below $40^{\circ} \mathrm{C}$ for two days. The sponge was then grinded into powder form.

\subsection{Extraction and Solvent Partitioning}

Approximately $500 \mathrm{~g}$ powder sample was extracted with methanol using a forma orbital shaker at the temperature of $37^{\circ} \mathrm{C}$ until the residue became colorless. The methanol extracts were filtered through Whatman No.1 filter paper fitted in a Buchner funnel using suction pressure and collected by concentration under reduced pressure by a rotary evaporator (Buchitype) to yield 37.55 gram of a dark gummy solid. Due to the saltiness of sample, the salt was then removed from the methanol extract using HP-20 and of lipid/ waxes using a C-18 catridge as described by Rosmiati et al. (2011b). The interfering material-free methanol crude extract was further partitioned with distilled 
water and diethyl ether (1:2 volume ratio) to give diethyl ether extract and an aqueous layer. The aqueous layer was partitioned with butanol $(3 \times 100 \mathrm{~mL})$ to yield butanol and an aqueous extract.

\subsection{Determination of Minimum Inhibitory Concentration (MIC) in Vitro}

The minimum inhibitory concentration was determined using the paper disc diffusion method as described by Bauer (1966). The Vibrio harveyi train (MR 275 Rif) was obtained from the Research Institute and Depelopment for Coastal Aquaculture collection. Mueller Hinton agar was used as culture media. Paper discs (6 $\mathrm{mm}$ in diameter) were individually impregnated with $20 \mu \mathrm{L}$ of the butanol extract at concentrations of $5,2.50,1.25,0.625,0.313,0.156,0.078$, and 0.039 $\mathrm{mg} / \mathrm{mL}$ and allowed to dry under a laminar air flow. After these paper discs were free of solvent, $100 \mu \mathrm{L}$ of the bacteria $\left(10^{7} \mathrm{CFUs} / \mathrm{ml}\right)$ was spread on Mueller Hinton agar plates and the paper discs were placed aseptically over the bacterial culture on $\mathrm{MH}$ agar plates and incubated at $37^{\circ} \mathrm{C}$ for 24 hours.

\subsection{Toxicity Test}

Seven days post larvae (PL-7) of black tiger shrimp, Penaeus monodon were collected from a commercial hatchery in Bone Regency, South Sulawesi, Indonesia. They were stocked in a fiber glass container ( $500 \mathrm{~L}$ ) in the wet laboratory of Research Institute for Coastal Aquaculture (RICA), Maros, Indonesia. The shrimp post larvae were acclimatized in the temperaturecontrolled wet laboratory and reared for 7 days prior to the start of the experiment (PL-14). During the rearing period, they were fed with commercial feed at $10 \%$ of body weight two times a day (06:00 and 18:00). The post larvae that were free of white spot (based on PCR test) and that were $\pm 1 \mathrm{~cm}$ in length size were selected. The butanol extract was diluted in distilled and sterilized sea water (30 ppt) to give $31.25,62.5,125,250$, and $500 \mathrm{ppm}$.

A toxicity test was used based on the soaking method as described by Zulham (2004) with some modifications. The post larvae in rearing units were treated with butanol extracts at those concentrations for 168 hours without water exchange. The larval rearing units consisted of conical shaped aquaria containing $1 \mathrm{~L}$ filtered and chlorinated seawater at $30 \mathrm{ppt}$. The density of 14 day old post larvae was 20 larvae/L for each unit. All rearing units were provided with gentle, continuous aeration. During the study, the post larvae were fed with commercial feed at $10 \%$ of body weight two times a day (06:00 and 18:00).
In this study, Completely Randomized Design was used with 6 treatments and 3 repetitions. The six treatments consisted of $A$. control (untreated $P L$ ); B. $(\mathrm{PL}+31.25 \mathrm{ppm}$ extract $) ; \mathrm{C}(\mathrm{PL}+62.5 \mathrm{ppm}$ extract); $D(P L+125$ ppm extract); $E$. (PL +250 ppm extract); and F. (PL + 500 ppm extract). Before each feeding, feces were removed by siphoning.

The enumeration of mortality/survivability was performed at hours $1,3,6,9$, and 12 and every 24 hours until seven days of rearing. The larvae were weighed initially and at the end of the study to determine absolute biomass growth. Clinical signs were monitored at the same time intervals as the enumeration of mortality/survivability. The palatability of tiger shrimp post-larvae was determined by removing fed consumption residue after two hours of feeding, drying by freeze dryer and weighing. Water quality was monitored daily and temperature and $\mathrm{pH}$ were measured using a HANNA instrument (HI $93715 \mathrm{YSI}$ ). Dissolved oxygen was estimated by a YSI, DO and temperature meter (YSI, model 57 , USA). The salinity of the rearing water was measured by a hand refractometer.

To determine any adverse effect of the extracts after seven days, three larvae from each experiment were harvested and fixed in a $10 \%$ buffered formalin solution for fixation, which were subsequently subjected to standard histology processing and procedures.

\subsection{Data Analysis}

Analysis of mortality/survivability data was performed by one way analysis of variance (ANOVA). When differences were found among the treatments, Tukey's test was used to compare means by SPSS Version 15.0 software packages (SPSS $®$ Inc., USA). Differences of results were considered statistically significant difference if the $P$ value were $\leq 0.05$.Whilst, clinical signs, palatability indicated by fed consumption residue, absolute biomass growth, and water quality were analyzed descriptively. The analysis of any adverse effect was via histological examination for any toxicological and abnormalities sign.

Mortality (\%) was obtained by equation:

Mortality $(\%)=100 \%$ - Survival Rate (SR)

Survival rate (SR) was counted by equation as followed:

$$
\mathrm{SR}=\frac{\mathrm{Nt}}{\mathrm{N} 0} \times 100 \%
$$

$\mathrm{SR}=$ Survival rate $(\%)$

$\mathrm{Nt}=$ Total of post-larvae in the time (individu)

N0 $=$ Total of post-larvae in the initial (individu) 


\subsection{Fed Consumption (FC)}

Fed consumption (FC) was counted by equation as followed: $\mathrm{FC} \%=(\mathrm{FT}-\mathrm{Ft}) \times 100 \%$

$\mathrm{FC}=$ Fed consumption $(\%)$

$\mathrm{Ft}=$ The weight of fed given in the time $(\mathrm{g})$

FCR $=$ The weight of fed consumption residue in the time $(\mathrm{g})$

\subsection{Absolute Biomass Growth (W)}

Absolute biomass growth (W) was counted by equation: $\mathrm{W}(\%)=(\mathrm{Wt}-\mathrm{Wo}) \times 100 \%$

$\mathrm{W}=$ Absolute biomass growth $(\mathrm{g})$

$\mathrm{Wt}=$ The weight mean of post-larvae in the end of study (g)

Wo $=$ The weight mean of post-larvae in the initial of study (g)

\section{Results and Discussion}

In vitro minimum inhibitory concentration (MIC), determinated by the paper disc diffusion method, showed that the MIC of Aaptos suberitoides butanol extracts was $0.313 \mathrm{mg} / \mathrm{mL}$ (Table 1). The low MIC value indicates that this extract strongly inhibits the growth of Vibrio harveyi. As mentioned by Aligiannis et al. (2001), active extracts with MIC values less than 1 $\mathrm{mg} / \mathrm{mL}$ are considered to be strongly active extracts; thus, these extracts have the potential to be developed as antibacterial agents in vibriosis treatment.

Observation of mortality of tiger shrimp post-larvae treated with different concentrations of $A$.suberitoides butanol extract after 168 hours rearing period is shown in Figure 1.

Figure 1 shows that treatment of $A$.suberitoides butanol extract with different concentrations resulted in adifferent effect on the mortality rate of tiger shrimp

Table 1.Antibacterial activity of Aaptos suberitoides butanol extract at various concentrations on Vibrio harveyi

\begin{tabular}{rc}
\hline Concentration $(\mathrm{mg} / \mathrm{ml})$ & Inhibition Zone $(\mathrm{mm}) \pm \mathrm{SD}$ \\
\hline 5 & $20 \pm 0.5$ \\
2.50 & $17 \pm 0.3$ \\
1.25 & $12 \pm 0.1$ \\
0.625 & $10 \pm 0.3$ \\
0.313 & $7 \pm 0.1$ \\
0.156 & - \\
0.078 & - \\
0.039 & - \\
0.039 & - \\
\hline
\end{tabular}

- No inhibition

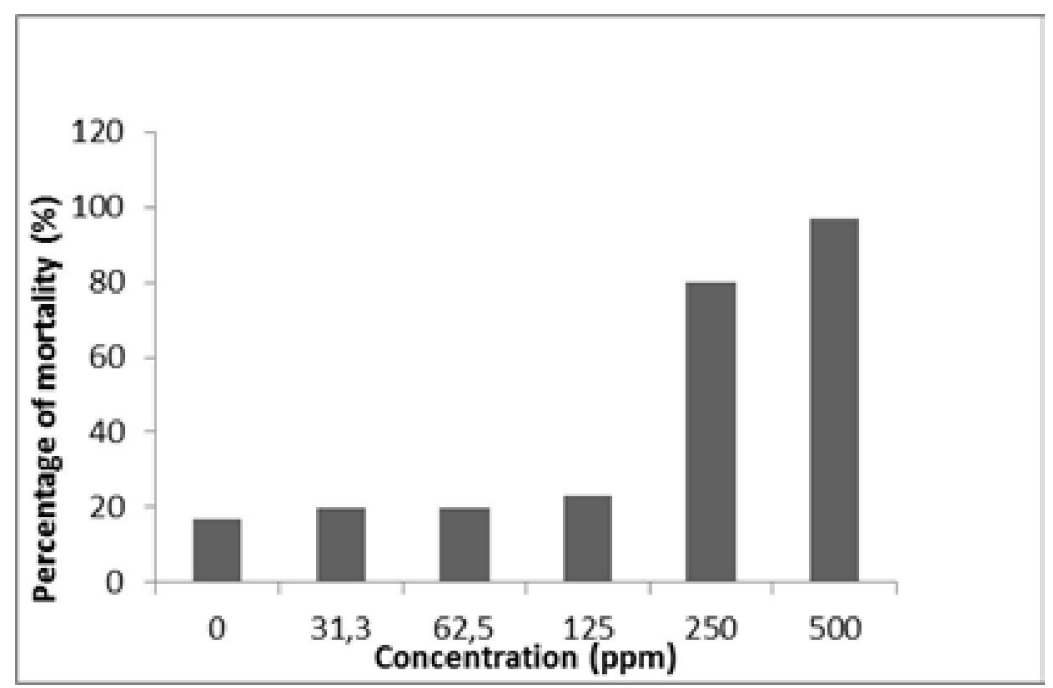

Figure 1. Graph of tiger shrimp post larvae mortality treated with different concentrations of Aaptos suberitoides butanol extract after 168 hours of rearing time period 
Table 2. Percentage of tiger shrimp-post larvae mortality treated with different concentrations of Aaptos suberitoides butanol extract during 168 hours of rearing time period in toxicity test

\begin{tabular}{|c|c|c|c|c|c|c|c|c|c|c|c|c|c|c|}
\hline \multirow[t]{2}{*}{ Code } & \multirow{2}{*}{$\begin{array}{l}\text { No.of } \\
\text { Ind. }\end{array}$} & \multicolumn{13}{|c|}{ Mortality (\%) } \\
\hline & & 1 & 3 & 6 & 9 & 12 & 24 & 36 & 48 & 72 & 96 & 120 & 144 & 168 \\
\hline A & 20 & 0 & 0 & 0 & 0 & 0 & 0 & 10.0 & 6.7 & 0 & 0 & 0 & 0 & 0 \\
\hline B & 20 & 0 & 0 & 0 & 0 & 0 & 0 & 10.0 & 0 & 10.0 & 0 & 0 & 0 & 0 \\
\hline $\mathrm{C}$ & 20 & 0 & 0 & 0 & 0 & 0 & 0 & 6.7 & 13.3 & 0 & 0 & 0 & 0 & 0 \\
\hline D & 20 & 0 & 0 & 0 & 0 & 0 & 0 & 10.0 & 13.3 & 0 & 0 & 0 & 0 & 0 \\
\hline$E$ & 20 & 0 & 0 & 0 & 0 & 0 & 10.0 & 15.0 & 10.0 & 13.3 & 16.7 & 0 & 5.0 & 10 \\
\hline $\mathrm{F}$ & 20 & 0 & 0 & 0 & 0 & 0 & 23.3 & 16.7 & 13.3 & 5.0 & 23.7 & 5.0 & 5.0 & 5.0 \\
\hline
\end{tabular}

Concentration: A. 0 ppm (control); B. 31.3 ppm; C. 62.5 ppm; D. 125 ppm; E. 250 ppm; and F. 500 ppm

post-larvae. The post larvae untreated with butanol extract gave the lowest mortality (16.7\%). Meanwhile, post larvae treated with butanol extract at the concentrations of 31.3 and $62.5 \mathrm{ppm}$ showed the same mortality namely $20.0 \%$, followed by treatment at the concentrations of $125 \mathrm{ppm}, 250$ and $500 \mathrm{ppm}$ with a mortality of $23.3 \%, 80.0 \%$ and $97.0 \%$, respectively. The mortality of $>50 \%$ showed by the post larvae treated with the concentrations of $>125$ ppm indicated that these concentrations were toxic. As earlier reported, this sponge contains saponin resulting lather formation (Rosmiati, 2013). The presence of lather in the rearing water disturbed respiration process of the post larvae. The mortality of post Iarvae treated with butanol extract at the concentrations of 250 and $500 \mathrm{ppm}$ had beed observed 24 hours post treatment as exhibited in Table 2.

From Table 2, the mortality of untreated post larvae $(0 \mathrm{ppm})$ could also be observed after 48 hours of rearing time period. It was suspected that the post-larvae were under stress condition and that some of the post-larvae tested could not adapt well under these environmental conditions. Another factor was the need for the postlarvae to molt. In this condition, the post-larvae were found to be weak. Because shrimp post-larvae are cannibals, the weak post-larvae could be wiped out by the other post-larvae. The weak post-larvae caused by molting were also suspected to be the cause of the mortality observed for the extract treatment of $B$, $C$ and $D 36,48$ and 72 hours post treatment.

Statistical analysis of the post larvae mortality rate at 168 hours of rearing time period indicates that the mortality rate of the post larvae treated with butanol extract of A.suberitoides at the concentratiosn of 31.3, 62.5 and $125 \mathrm{ppm}$ showed no any significant difference effect $(P>0.05)$ than that of the control (extract untreated post larvae). The similar result was also displayed by the treatments of $E$ and $F$. However, these treatments gave a significant effect to treatments of $B, C$ and $D$ as well as $A$ (control). This finding showed that $A$. suberitoides butanol extract at the concentrations of $31.3,62.5$ and $125 \mathrm{ppm}$ were non toxic on tiger shrimp post larvae. It was suspected that at these concentrations, the extract did not result an unpleasant smell which could disturb appetite of post larvae.

The tiger shrimp post-larvae treated with various concentrations of butanol extract $A$.suberitoides showed the different response of clinical signs. Treatment with butanol extract at a concentration of 250 and $500 \mathrm{ppm}$ in the first day resulted in a common abnormal behavior in which shrimp post-larvae often swim to the surface. Shortly thereafter, the post-larvae turn upside down and finally sink to the bottom and die. Meanwhile, post larvae treated with 0, 31.3, 62.5, and $125 \mathrm{ppm}$ showed normal appetites, were always observed on the base of aquaria and exhibited normal swimming behavior, which indicated healthy post larvae.

The palatability of tiger shrimp post larvae could be determined through feed consumption residue percentage. The percentage of feed consumption residue observed during the seven days rearing time period is shown in Figure 2

As shown in Figure 2, post larvae treated with butanol extract at the concentrations of 250 and 500 ppm on the first and second day lost appetitive indicated by the high feed consumption residue $>50$ $\%)$. However, there was a drastic decrease on the third day and continued to gradually decrease. In contrast, post larvae treated with butanol extract at the concentrations of $31.3,62.5$ and 125 ppm exhibited a fluctuating feed consumption residue with the highest increase namely $25 \%$ occurred on the second and third day. The similar pattern was also shown by untreated post larva $(0 \mathrm{ppm})$ with the highest feed consumption residue $(25 \%)$ occurred on the fourth day during this study. Mortality of the post larvae treated with the extract at the concentration of 250 and $500 \mathrm{ppm}$ was due to the loss of their appetite caused by the toxic effect of the butanol extract at these concentrations. This study also shows that the 


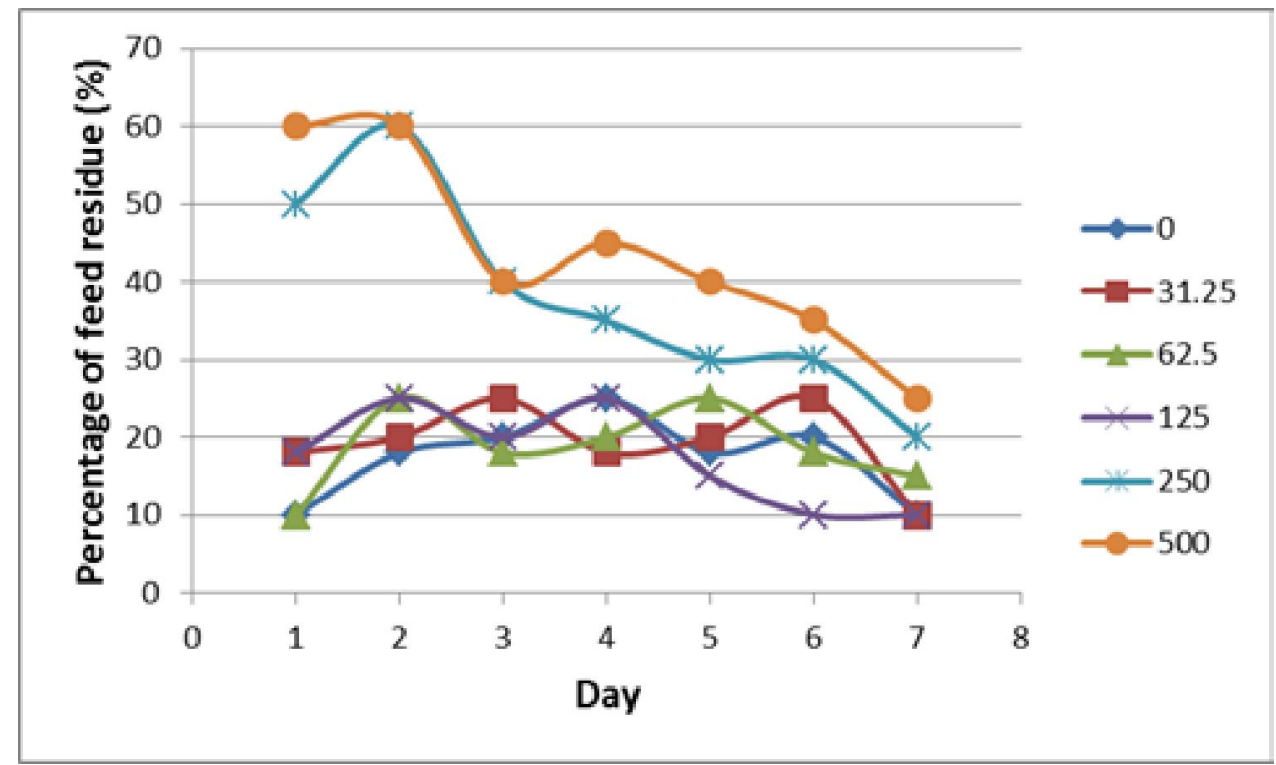

Figure 2. Graph of feed consumption residue percentage of post larvae treated with various concentrations of Aaptos suberitoides butanol extract during seven days rearing time period

best clinical condition was observed for the treatments of $31.3,62.5$ and $125 \mathrm{ppm}$. The post larvae were observed actively eating and spending more time on the base of the aquaria. Similar signs were also observed with the untreated shrimp post-larvae (control). These results indicate that treating A.suberitoides butanol extracts at the lower concentration caused better digestion for post larvae. This phenomenon was indicated by the decreased feed consumption residue and softer feces.

Body color was another sign of the effect of extract concentration on post larvae. The post larvae that were given the extract treatment with a concentration of $31.3,62.5$ and $125 \mathrm{ppm}$ exhibited clear body color similar to that observed on control post larvae, indicating healthy normal post larvae. In contrast, for treatment of higher concentration extracts (250 and $500 \mathrm{ppm}$ ), the bodies of post larvae looked brown due to the uptake of concentrated extract.
Treatment of $A$.suberitoides butanol extract into rearing water affected the absolute biomass growth of tiger shrimp Penaeus monodon post larvae as shown in Table 3. Table 3 shows that the absolute biomass growth of post larvae declined together with the increased concentration of butanol extract. Compared to control, the absolute biomass growth shown by post larvae treated with butanol extract at the concentrations of $>62.5 \mathrm{ppm}$ was lower. For the extract treatment of $31.3 \mathrm{ppm}$, the highest absolute biomass growth average $(0.0415 \mathrm{~g})$ was obtained. The lowest absolute biomass growth was found on the concentration of $500 \mathrm{ppm}$.

The post larvae treatment with butanol extract at a concentration of $31.3 \mathrm{ppm}$ resulted in not only the decreased mortality but also the increased absolute biomass growth of tiger shrimp post larvae. For this extract concentration, the post larvae exhibited more active eating behavior, as mentioned above. This

Table 3. Absolute biomass growth of post larvae treated with various dosages of Aaptos suberitoides butanol extract after seven days of rearing time

\begin{tabular}{cc}
\hline Concentration (ppm) & Average/ind. (g) \\
\hline 0 & 0.0400 \\
31.3 & 0.0415 \\
62.5 & 0.0390 \\
125 & 0.0350 \\
250 & 0.0240 \\
500 & 0.0220 \\
\hline
\end{tabular}


Table 4. The water quality of tiger shrimp post-larvae treated with various concentrations of Aaptos suberitoides butanol extract during rearing time

\begin{tabular}{cccc}
\hline Concentration $(\mathbf{p p m})$ & $\mathbf{p H}$ & $\begin{array}{c}\text { Temperature } \\
\left({ }^{\circ} \mathbf{C}\right)\end{array}$ & $\begin{array}{c}\text { Dissolved } \\
\text { Oxygen }(\mathbf{m g} / \mathbf{L})\end{array}$ \\
\hline 0 & $7.55-7.84$ & $26.0-26.3$ & $5.33-8.00$ \\
31.3 & $7.60-7.79$ & $25.5-26.3$ & $6.56-7.79$ \\
62.5 & $7.63-7.81$ & $25.7-26.0$ & $6.61-7.90$ \\
125 & $7.55-7.84$ & $25.6-26.1$ & $7.11-7.97$ \\
250 & $7.73-7.87$ & $25.5-26.0$ & $7.16-7.96$ \\
500 & $7.50-7.71$ & $25.6-26.0$ & $7.22-7.88$ \\
\hline
\end{tabular}

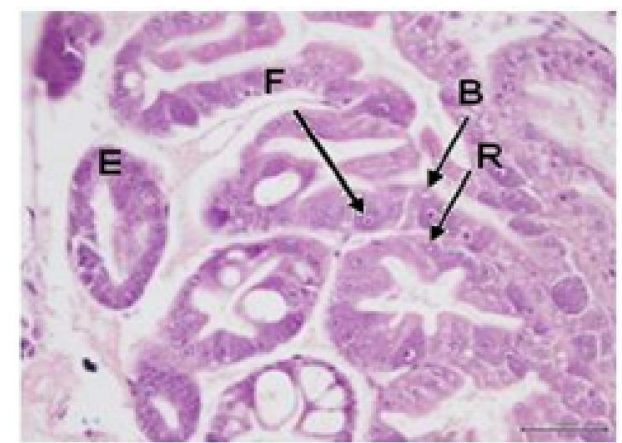

A. $0 \mathrm{ppm}$
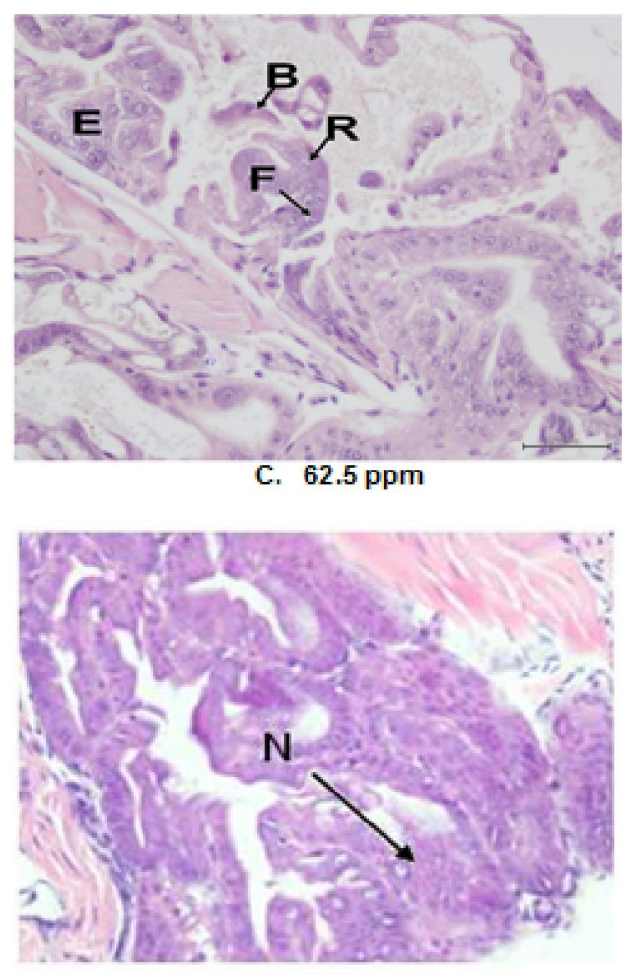

E. $250 \mathrm{ppm}$

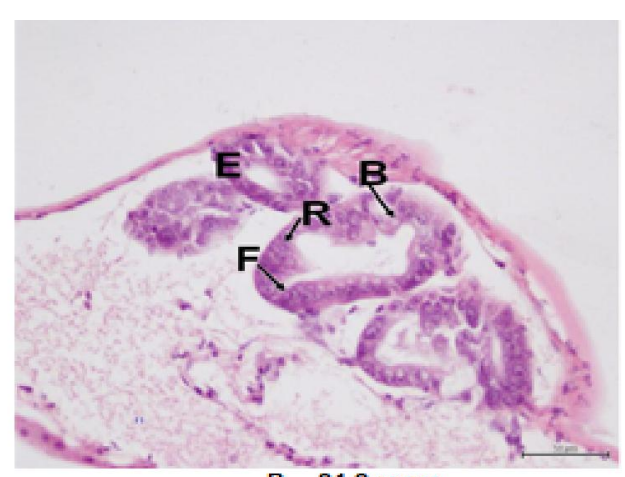

B. $31.3 \mathrm{ppm}$

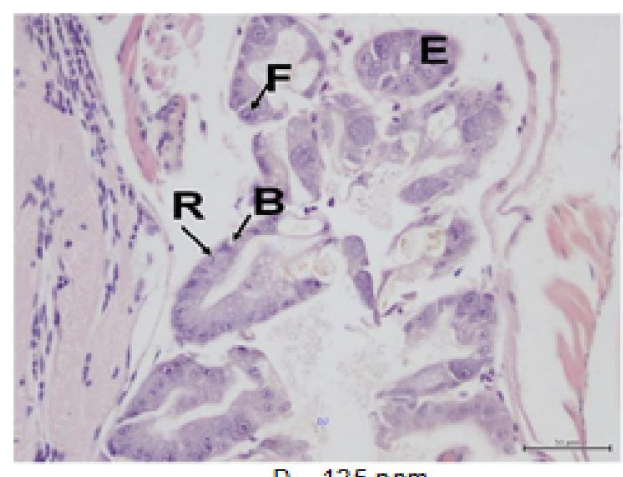

D. $125 \mathrm{ppm}$

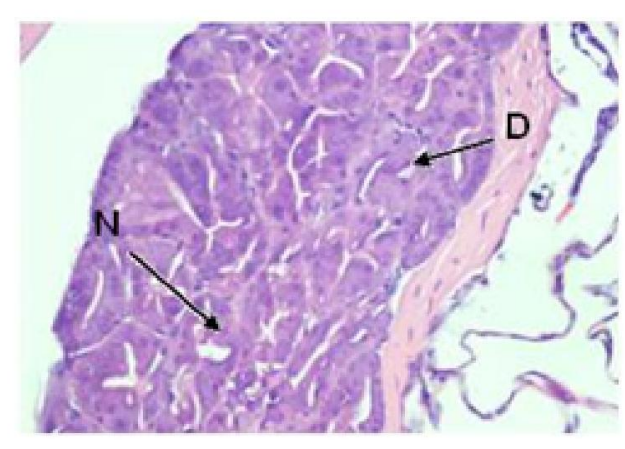

F. $500 \mathrm{ppm}$

Figure 3. Effect of Aaptos suberitoides butanol extract on haepatopancreas of tiger shrimp post larvae treated with the concentration of 0 ppm (a); 31.3 ppm (b); $62.5 \mathrm{ppm}$ (c); $125 \mathrm{ppm}$ (d); $250 \mathrm{ppm}(\mathrm{e})$; and 500 ppm (f). E=Embryonic cell; B=Blasenzellen cell; $R=$ Restzellen cell; $F=F$ ibrillazellen cell; $D=F a t t y$ degeneration; and $\mathrm{N}=$ Cell necrosis. Haematoxylin and Eosin Staining, Magnification $=40 \mathrm{x}$. 
condition influenced the high absolute biomass growth after seven days of rearing. Meanwhile, post larvae treated with butanol extract at the concentrations of 62.5 and $125 \mathrm{ppm}$ showed an absolute biomass growth less than the control. In contrast, post larvae treated with extract at the concentrations of 250 and $500 \mathrm{ppm}$ gave a much lower absolute biomass growth.

Water quality is critical for survival, health and growth of prawns. To maintain good water quality, the physical and chemical properties of water should be maintained within certain safe levels. The monitoring of $\mathrm{pH}$ of the rearing water showed that the range of $\mathrm{pH}$, temperature and dissolved oxygen was in an optimal condition for tiger shrimp post larvae growth (Table 4). This finding indicates that the mortality of the post larvae was caused by the A.suberitoides butanol extract treatment.

From Table 4, it was determined that the $\mathrm{pH}$ value observed during post larvae rearing range from 7.50 to 7.87. Parado-Estepa et al. (1996) reported that the optimum $\mathrm{pH}$ for $P$. monodon is 7.5 to 8.5 . $\mathrm{pH}$ is one of the vital environmental characteristics that determines the survival and growth of shrimp under culture and it also affects the metabolism and other physiological processes of shrimp (Syafiuddin, 2000). Table 4 also shows the temperature of rearing water ranging among $25.5-26.3^{\circ} \mathrm{C}$. Soundarapandian et al. (2010) reported that for optimum growth of Penaeus monodon, the optimum range of temperature was between 25 to $31^{\circ} \mathrm{C}$ and that of dissolved oxygen was between 4 to $8 \mathrm{mg} / \mathrm{L}$ (Syafiuddin, 2000). Water temperature is likely the most important environmental variable in shrimp culture because it directly affects metabolism, oxygen consumption, growth, molting, and survival. $P$. monodon is sensitive to temperature changes in water. When the temperature is below $13^{\circ} \mathrm{C}$ or above $33^{\circ} \mathrm{C}$, the prawns typically develop cramps and die. Meanwhile dissolved oxygen (DO) plays an important role in growth and production through its direct effect on feed consumption and maturation. Salinity observed during the post larvae rearing did not show any change (30 ppt).

The histological analysis on tiger shrimp post larvae demonstrated that there were no toxicity effects or abnormal changes in haepatopancreas caused by butanol extract treatments with concentrations of 31.3 ppm (B) (Figure 3B) and $62.5 \mathrm{ppm}(\mathrm{C})$ (Figure 3C) and $125 \mathrm{ppm}$ (D) (Figure 3D) compared to the control (A) (Figure $3 A$ ) after seven days of rearing period. Tiger shrimp post larvae treated with butanol extract at the concentration of $31.3,62.5$ and $125 \mathrm{ppm}$ showed the lumen containing a granular material and the lumenfacing surface on the tubule was covered with a microvillus border. In addition, the tubular apex contained undifferentiated embryonic cells ( $E$ cells). $R$ cells, $B$ cells and $F$ cells were also observed and $F$ cells nuclei were larger than those of $R$ cells, which characteristically contained numerous nuclei. In contrast, tiger shrimp post larvae treated with butanol extract of the concentration 250 and 500 ppm exhibited tissue changes of the hepatopancreas. The tissue changes obtained with a treatment of $250 \mathrm{ppm}$ was the occurrence of cell necrosis indicating the toxic effect of the butanol extract. Cell necrosis was also observed in post larvae haepatopancreas treated with butanol extract at the concentration of $500 \mathrm{ppm}$ included the presence of multifocal fatty degeneration, which caused the loss of $B$ cells.

\section{Conclussions}

Treatment of tiger shrimp Penaeous monodon post larvae with butanol extract Aaptos suberitoides at the concentrations of $31.3,62.5$, and $125 \mathrm{ppm}$ gave no difference in mortality compared with the control. It was found that there is no toxic effect of such extract treatment on haepatopancreas of tiger shrimp post larva, suggesting that butanol extract of $A$.suberitoides has a potential to be developed for vibriosis treatment.

\section{Acknowledgements}

The authors gratefully acknowledges to Wahyuni, staff at Disease Investigation Center, Maros for histological analysis and to Hasanuddin Universiti's divers for sponge collection. This work was financially supported by South Sulawesi Goverment.

\section{References}

Aligiannis, N., Kalpotzakis, E., Mitaku, S., \& Chinou, I.B. (2001). Composition and antimicrobial activity of the essential oils of two Origanum species. Journal ofAgricultural and Food Chemistry, 40, 4168-4170.

Baticados, M. C. L., Lavilla-Pitogo, C. R., Cruz-Lacierda, E. R., de la Pena, L. D., \& Sunaz, N. A. (1990). Studies on the chemical control of luminous bacteria Vibrio harveyi and V.splendidus isolated from diseased Penaeus monodon larvae and rearing water. Dis Aquat. Org., 9, 133-139.

Bauer, A. W., Kirby, W. M., Sherris, J. C., \& Turck, M. (1966). Antibiotic susceptibility testing by a standardized single disc method. American Journal of Clinical Pathology, 45, 493-496.

Chen, F. R., Liu, P. C., \& Lee, K. K. (2000). Lethal attribute of serine protease secreted by Vibrio alginolyticus strains in Kurama Prawn Penaeus japonicus. Zool Naturforsch, 55, 94-99.

Inouye, K. (1996). An overview of health management of coldwater fish and shrimp in Japanese 
aquaculture. In Health Management in Asian Aquaculture (Ed) R.P. Subasinghe, J.R. Arthur and M. Shariff, Rome: FAO Fisheries Technical Paper. pp 104-114,.

Isnansetyo, A., Trijoko., Setyowati, E.P., \& Anshory, H. H. (2009). In vitro antibacterial activity of methanol extract of a sponge, Geodia sp. against oxytetracyclinresistent Vibrio harveyi and its toxicity. J. Biol. Sci.,9: 224-230.

Karunasagar, I., Vinod, M.G., Kennedy, B., Vijay, A., Deepanjali, K. R., \& Umesha, K.R.(2005). Biocontrol of bacterial pathogens in aquaculture with emphasis on phage therapy. In Walker, P.J., Lester, R.G., BondadReantaso, M.B. (Ed) Diseases in Asian Aquaculture, vol. V. Fish Health Section, Asian Fisheries Society, Manila, pp. 535.

Khodria, I. A. K.(2012).Development of rapid detection methods of Vibriosis diseases in penaeid shrimp aquaculture. Ph.D. Thesis. Institute Pertanian Bogor.

Lavilla-Pitogo, C.R., Baticados, M.C.L., Cruz- Lacierda, E.R.,\& de la Pena, J.D. (1990). Occurrence of luminous bacterial disease of Penaeus monodon larvae in the Philippines. Aquaculture. 91: 1-13.

Lavilla-Pitogo, C.R., Leano, E.M.,\& Paner, M.G. (1996). Mortalities of pond cultured juvenile shrimp, Penaeus monodon, associated with dominance of luminescent bacteria, Vibrio harveyi in the rearing environment. SICCPPS book of abstracts, SEAFDEC, Iloilo City, Philippines. p. 40

Ninawe, A. S. (2007). Marine organisms are a promising new source of bioactive substances.Drug Discovery \& Development Magazine 10 (2):46-49.

Parado-estepa, F.D., Quinitio, E.T.,\&Borlongan, E.L. (1996). Prawn Hatchery Operations. Philippines: Southeast Asian Fisheries Development Center.

Pasharawipas, (2011). Inducible viral receptor, a possible concept to induce viral protection in primitive immune animals. Virology Journal 8:326.

Prayitno, S.B.\& Latchford, J.W. (1995). Experimental infection of crustaceans with luminous bacteria related to Photobacterium and Vibrio. Effect of salinity and $\mathrm{pH}$ on infectiosity. Aquaculture132:105-112.

Raffi, S.M., and Suresh, T.V. (2011). Screening of Chloramphenicol in wild and cultured shrimp Penaeus monodon by Competitive Enzyme Linked Immunosorbent Assay. International Conference on Chemical, Biological and Environment Sciences (ICCEBS'2011). Bangkok

Robertson, P. A. W., Calderon, J., Carrera, L., Stark, J. R., Zherdmant, M.,\& Austin, B. (1998). Experimental Vibrio harveyi infections in Penaeus vannamei larvae. Dis. Aquat. Organ.32:151-155.

Rosmiati., Habsah,M.,\& Muhammad, T.S.T. (2011a). Biological activities of methanolic extracts of several sponge species in $10^{\text {th }}$ International Annual Symposium of Universiti Malaysia Terengganu, th1113 of July in Kuala Terengganu, Malaysia.
Rosmiati., Parenrengi, A., \& Suryati, E. (2014). Marine sponge Aaptos suberitoides, the potential source of natural antibacterial for controlling Vibrio harveyi on tiger shrimp (Penaeous monodon ) culture. Aceepted on Indonesian Aquaculture Journal (on going).

Rosmiati. (2013). Vibriosis prevention and antiatherosclerosis secondary metabolites from marine sponge Aaptos aaptos and Callyspongia pseudoreticulata. Ph.D Thesis. Universiti Malaysia Terengganu.

Selvin, J., \& Lipton, A.P. (2004). Dendrilla nigra, a marine sponge, as potential source of antibacterial substances for managing shrimp diseases. Aquaculture 236: 277-283.

Selvin, J., Manilal, A., Sujith, S., Kiran, G.s.,\& Lipton, A. P. (2011). Efficacy of marine green alga Ulva fasciata extract on the management of shrimp bacterial diseases. Lat. Am. J. Aquat. Res. 39(2):197-204.

Sengupta, D., Ray., P. K.,\& Bhat, G. S. (2003). Spring warming of the eastern Arabian Sea and Bay of Bengal from buoy data. Geophys. Res. Lett.29(15):1734.

Sunaryanto, A., \& Mariam, A. (1986). Occurrence of pathogenic bacteria causing luminescent in Penaeid larvae in Indonesia hatcheries. Bull. Brackish Water Aqua. Dev. Cent. 8(2): 64-70.

Suryati, E., Ahmad, T.\& Muliani (1997). Analisis bioaktif bunga karang Auletta $s p$ yang aktif terhadap bakteri Vibrio $s p$ pada udang. Makalah disajikan pada Seminar Nasional Hasil Penelitian dalam Bidang Farmasi. Pages Dalam Rangka Peringatan 50 Tahun Pendidikan Farmasi ITB, September, Bandung, Indonesia.

Suryati, E., Muliani., \& Parenrengi, A. (1998). Analisis serta pemanfaatan bioaktif bunga karang Halichondria sp. yang aktif menghambat pertumbuhan bakteri Vibrio sp. pada udang. Prosiding Simposium Perikanan Indonesia II. Pages 192-194. Jakarta: Lembaga IImu Pengetahuan Indonesia.

Soundarapandian, P., \& Babu, R. (2010). Effect of Probiotics on the Hatchery Seed Production of Black Tiger Shrimp, Penaeus monodon (Fabricius). International Journal of Animal and Veterinary Advances 2(1): 9-15.

Syafiuddin, 2000. Kinerja budidaya udang windu Penaeus monodon Fab. yang dipelihara bertingkat dalam sistem resirkulasi. Master Thesis, Institute Pertanian Bogor, Bogor.

Tansutapanit, D.S.O.A., \& Ruangpan, L.(1987). Vibrio harueyi a causative agent of mortality in white shrimp naulpii, Penaeus merguiensis In: Abstract. Tech. Paper No. 6/30. Third Natl. Seminar on Marine ScienceNSRC, Bangkok/.

Tanticharoen, M. (2008).Aquacultural biotechnology in Thailand: the case of the shrimp industry. Int. J. Biotechnology10 (6): 588-603.

Traifalgar, R. F. M., Corre, V. L.,\&Serrano, A. E. (2013). Efficacy of dietary immunostimulants to enhance the immunological responses and Vibriosis resistance 
Squalen Bulletin of Marine \& Fisheries Postharvest \& Biotechnology, 9 (2), 2014, 75-84

of juvenile Penaeus monodon. Journal of Fisheries and Aquatic Science8(2): 340-354.

Usman, H. (2013). The prevention of Vibriosis on tiger shrimp Penaeus monodon post larvae using leaves extract of Chromolaena odorata as natural bactericide. Ph.D. Thesis. Institut Pertanian Bogor.
Zulham, R., (2004). Potensi extract mangrove Sonneratia caseolaris dan Avicenia marina untuk pengendalian bakteri Vibrio harveyi pada larva udang windu (Penaeus monodon Fabr.), Master Thesis. Institute Pertanian Bogor. 